\title{
RAT SERUM CARBOXYLESTERASE PARTLY HYDROLYSES GAMMA-BUTYROBETAINE ESTERS
}

\author{
Lida BAGDONIENË $\dot{1}^{1}$, Danute LABEIKYTE் ${ }^{1}$, Ivars KALVIN̦Š2 ${ }^{2}$, Veronika BORUTINSKAITÉ³ \\ Aleksandrs PROKOFJEVS ${ }^{2}$, Pēteris TRAPENCIERIS ${ }^{2}$, Benediktas JUODKA ${ }^{1}$, and \\ Nikolajs SJAKSTE ${ }^{2}$
}

Department of Biochemistry and Biophysics, Vilnius University, Vilnius, Lithuania ${ }^{1}$, Latvian Institute of Organic Synthesis, Riga, Latvia², Department of Developmental Biology, Institute of Biochemistry, Vilnius, Lithuania ${ }^{3}$

Received in September 2008

Accepted in November 2008

\begin{abstract}
Although described some time ago, gamma-butyrobetaine esters and related compounds have not gained much attention from researchers, and their physiological function remains obscure. Formerly we detected GBB-esterase enzymatic activity in rat blood serum using phenylated gamma-butyrobetaine as an artificial substrate of the enzyme and HPLC. The aim of the present work was to develop an assay that would enable spectrophotometric or colorimetric determination of the reaction products of GBB-esterase activity and to reveal individual proteins performing GBB-esterase activity in rat blood serum. For this purpose gammabutyrobetaine 1-naphthyl ester was synthesised. Hydrolysis of this ester releases 1-naphthol, which increases the optical absorbance at $322 \mathrm{~nm}$. We have shown that the enzymatic hydrolysis of GBB 1-naphthyl ester to 1-naphthol in rat blood serum is due to GBB-esterase activity. An attempt was done to purify the enzyme from rat blood serum. By combining DEAE Sepharose at $\mathrm{pH} 4.2$ and affinity chromatography with procainamide we achieved a 68 -fold enrichment of GBB-esterase activity in our preparations. Separation of fraction proteins in 2D protein electrophoresis with following mass-spectrometry indicated that GBB esterase activity in rat blood serum is performed in part by carboxylesterase.
\end{abstract}

KEY WORDS: 1-naphtol, 2D electrophoresis, colorimetry, HPLC, spectrophotometry

Although described some time ago, gammabutyrobetaine esters and related compounds have not gained much attention from researchers. Numerous studies performed by E. Hosein et al. in the 1960s and 1970s suggest that these compounds have multiple functions (1-4). For example, in addition to being a carnitine precursor, gamma-butyrobetaine (GBB) can undergo esterification in mammalian brain tissue (4). The structure of GBB ethyl ester strikingly resembles that of acetylcholine. The distance between positively and negatively charged poles in both molecules is almost identical. The existence of a specific signal transfer system based on GBB esters was suggested recently (5-7), hypothesis was based on increase in GBB levels in stressed animals (8) and cholinergic activity of GBB esters (3). Seeking for arguments that support this hypothesis, in a series of experiments we established GBB-esterase enzymatic activity in rat blood serum using phenylated gammabutyrobetaine as an artificial substrate of the enzyme (9). The aim of this study was to develop an assay for spectrophotometric or colorimetric determination of GBB-esterase reaction products and to identify individual proteins performing GBB esterase activity in rat blood serum.

\section{MATERIALS AND METHODS}

Reagents. DEAE-Sepharose Fast Flow, Heparin Sepharose CL- B and CNBr-activated Sepharose TM 
4B were supplied by GE Healthcare Life Sciences (Sweden). Bio Gel P 150 was from BioRad, USA. Polygram SIL G/UV ${ }_{254}$ plastic sheets $(40 \mathrm{~mm} x$ $80 \mathrm{~mm}$ ) were from Macherey-Nagel (Germany) and polyethylene glycol 20000, 6-aminocaproic acid from Roth (Germany). Fast Blue RR salt and carboxylesterase from horse liver was from Fluka (USA), and acetylthiocholine iodide from Acros organics (USA).

BW 284c51 (1,5 bis $\{4$-allyldimethyl ammonium phenyl\} pentane-3-one-dibromide), tetraisopropylpyrophosphoramide (iso-OMPA), butyrylcholine chloride, and procainamide, 1(3-dimethylamino-propyl)-3-ethylcarbodiimide hydrochloride were from Sigma (Germany).

\section{Blood serum}

All manipulations with animals were performed upon Ethics Committee approval and in accordance with Lithuanian and Latvian regulations, which are compliant with EU rules. Blood was obtained from male Wistar rats decapitated under slight ether narcosis. Collected blood was stored at $37^{\circ} \mathrm{C}$ for $2 \mathrm{~h}$ and then centrifuged at $5000 \mathrm{~g}$ for $20 \mathrm{~min}$ to obtain serum in the supernatant. Serum was stored at $4{ }^{\circ} \mathrm{C}$ until used (up to 3 to 10 days).

\section{GBB esterase activity measurement}

GBB esterase activity was measured on a Perkin Elmer Lambda-20 spectrophotometer using GBB 1naphthyl ester (GBB-O-NF) as substrate essentially as described by Morgan et al. (10). Briefly, the hydrolysis of GBB-O-NF to 1-naphthol was observed through increase in absorbance at $322 \mathrm{~nm}$ (the extinction coefficient for 1-naphthol is $2.2 \mathrm{~L} \mathrm{mmol}^{-1} \mathrm{~cm}^{-1}$. The reactions were conducted in a cuvette $(\mathrm{V}=1 \mathrm{~mL})$ and initiated by adding substrate $\left(10 \mu \mathrm{L}\right.$ of $10 \mathrm{mmol} \mathrm{L}^{-1}$ stock in water). Initial velocities were measured in $1 \mathrm{~mL}$ of the assay mixture composed of 100 mmol L ${ }^{-1}$ of sodium phosphate buffer, $\mathrm{pH} 7.4 ; 0.1 \mathrm{mmolL}^{-1}$ GBB-O-NF, and serum or fractionated enzyme preparation at $25^{\circ} \mathrm{C}$ for $10 \mathrm{~min}$. In the measurements, the spontaneous hydrolysis of GBB-O-NF and the effects of additives on substrate hydrolysis were eliminated by using blank tubes containing appropriate combinations of compounds. The unit of GBB-O-NF esterase was defined as the amount of enzyme which catalyzes the formation of $1 \mu \mathrm{mol}$ of the product per min under these conditions.
The effects of potential GBB-O-NF esterase inhibitors were measured on a Perkin Elmer Lambda20 spectrophotometer using GBB-O-NF as substrate. The reactions were performed after preincubation of enzymatically active fractions with additive $(0.1 \mathrm{mmol}$ $\mathrm{L}^{-1}$ ) for $30 \mathrm{~min}$. Subsequently, GBB-O-NF was added to a final concentration of $0.1 \mathrm{mmol} \mathrm{L}^{-1}$, and absorbance was monitored at $322 \mathrm{~nm}$ to determine hydrolysis products. Initial velocities were measured in $1 \mathrm{~mL}$ of the assay mixture composed of $100 \mathrm{mmol}$ $\mathrm{L}^{-1}$ sodium phosphate buffer, $\mathrm{pH} 7.4$ and tested compounds at $25^{\circ} \mathrm{C} .50 \mu \mathrm{L}$ ( $30 \mu \mathrm{g}$ of protein) of the fraction fractionated on DEAE Sepharose and $10 \mu \mathrm{L}$ (10 $\mu \mathrm{g}$ of protein, $\left.0.5 \mathrm{U} \mathrm{mg}^{-1}\right)$ of carboxylesterase from horse liver were taken for measurements.

\section{Dialysis of rat serum}

$10 \mathrm{~mL}$ of serum was dialysed against $0.02 \mathrm{~mol} \mathrm{~L}^{-1}$ sodium acetate buffer $\mathrm{pH} 4.5$ containing $1 \mathrm{mmol} \mathrm{L}^{-1}$ EDTA for $12 \mathrm{~h}$, and against $0.02 \mathrm{~mol} \mathrm{~L}^{-1}$ sodium acetate $\mathrm{pH} 4.2$ containing $1 \mathrm{mmol} \mathrm{L}^{-1}$ EDTA for $3 \mathrm{~h}$.

\section{DEAE Sepharose chromatography at pH 4.2.}

$10 \mathrm{~mL}$ of dialysed serum (700 $\mathrm{mg}$ of total protein) were applied to a DEAE Sepharose column $(0.8 \mathrm{~cm}$ x $14 \mathrm{~cm}$ ), eluted with $25 \mathrm{~mL}$ of $0.02 \mathrm{~mol} \mathrm{~L}^{-1}$ sodium acetate buffer at $\mathrm{pH} 4.2$, then with 1:1 gradient of $(0$ to 0.15$) \mathrm{mol} \mathrm{L}^{-1} \mathrm{NaCl}$ in $0.02 \mathrm{~mol} \mathrm{~L}^{-1}$ sodium acetate buffer $\mathrm{pH} 4.2$, containing $1 \mathrm{mmol} \mathrm{L}^{-1}$ EDTA. The flow rate was $0.3 \mathrm{~mL} \mathrm{~min}^{-1}$. Fractions were concentrated with polyethylenglycol 20000 .

\section{Procainamide - Sepharose 4B chromatography}

Procainamide gel was synthesised according to the method of Cuatrecasas (11). Briefly, $3 \mathrm{~g}$ of waterswollen CNBr-activated Sepharose 4B was washed with water and $1 \mathrm{mmol} \mathrm{L}^{-1} \mathrm{HCl}(\mathrm{V}=20 \mathrm{~mL})$ three times each. Washed CNBr-activated Sepharose $4 \mathrm{~B}$ was then coupled with 6-aminohexanoic acid $(0.26 \mathrm{~g})$ in 0.2 mol L-1 $\mathrm{Na}_{2} \mathrm{CO}_{3} / \mathrm{NaHCO}_{3} \mathrm{pH} 8.3$ buffer containing $0.5 \mathrm{~mol} \mathrm{~L}^{-1} \mathrm{NaCl}$. Excess of ligand was removed by washing, and the remaining active groups were blocked with $0.1 \mathrm{~mol} \mathrm{~L}^{-1}$ Tris-HCl buffer at $\mathrm{pH}$ 8.0. Procainamide $\left(0.275 \mathrm{~g} ; 100 \mu \mathrm{mol} \mathrm{mL}^{-1}\right.$ of gel) was coupled with $10 \mathrm{~mL}$ of 6-aminohexanoic Sepharose 4B by adding $10 \mathrm{~mL}$ of $0.2 \mathrm{~mol} \mathrm{~L}^{-1} 1$-(3-dimethylaminopropyl)-3-ethylcarbodiimide hydrochloride $(0.38 \mathrm{~g})$, maintaining the $\mathrm{pH}$ at 4.5 with $1 \mathrm{~mol} \mathrm{~L}^{-1} \mathrm{HCl}$ for $2 \mathrm{~h}$ and then stirring at room temperature $(20$ to 25$){ }^{\circ} \mathrm{C}$ for $24 \mathrm{~h}$. The gel was washed three times with $20 \mathrm{~mL}$ of 
water. The concentration of procainamide bound to the gel was determined by measuring the absorbance of the washings $\left(\varepsilon=16150 \mathrm{~L} \mathrm{~mol}^{-1} \mathrm{~cm}^{-1}\right.$ at $\left.278 \mathrm{~nm}\right)$. The difference between the starting amount and the amount in the washings gave the gel-bound concentration. Affinity columns $(0.8 \mathrm{~cm} \times 5 \mathrm{~cm})$ were equilibrated with $20 \mathrm{mmol} \mathrm{L}^{-1}$ potassium phosphate and $1 \mathrm{mmol}$ $\mathrm{L}^{-1}$ EDTA $\mathrm{pH}$ 7, and washed with $20 \mathrm{~mL}$ of $20 \mathrm{mmol}$ $\mathrm{L}^{-1}$ potassium phosphate and $1 \mathrm{mmol} \mathrm{L}{ }^{-1} \mathrm{EDTA} \mathrm{pH}$ 7.0. The column was then eluted with $38 \mathrm{~mL}$ of 0.2 mol L ${ }^{-1} \mathrm{NaCl}$ in buffer. Finally, the proteins more tightly bound to procainamide were eluted with $40 \mathrm{~mL}$ of $1 \mathrm{~mol} \mathrm{~L}^{-1} \mathrm{NaCl}$ in $20 \mathrm{mmol} \mathrm{L}^{-1}$ potassium phosphate, $1 \mathrm{mmol} \mathrm{L}^{-1}$ EDTA pH 7.0. Fractions were concentrated with polyethylenglycol 20000.

SDS gel electrophoresis was performed according to Laemmli (12). $10 \%$ gels were run at $120 \mathrm{~V}$ constant voltage for $4 \mathrm{~h}$. Gels were stained with the Coomassie dye.

\section{Nondenaturing gel electrophoresis}

Fractions containing $30 \mu \mathrm{g}$ total protein per lane were subjected to electrophoresis in 3\% acrylamide stacking gel and $7.5 \%$ acrylamide separating gel, and run at constant voltage $(120 \mathrm{~V})$ for $4 \mathrm{~h}$. After electrophoresis, the gels were washed for $15 \mathrm{~min}$ in $100 \mathrm{mmol} \mathrm{L}^{-1}$ sodium phosphate buffer (pH 6.8), and stained as described below.

\section{D electrophoresis (IEF/SDS-PAGE)}

The samples were dissolved in sample buffer $(12 \mathrm{~g}$ urea, $50 \mathrm{mg}$ DTT, $0.13 \mathrm{~mL}$ farmalit $3-10,0.13 \mathrm{~mL}$ Triton X-100, water to $25 \mathrm{~mL}$ ). Immobiline Dry Strips 3-10 and 4-7 (11 cm) (Amersham Biosciences) were used for the first dimension. Dry strips were rehydrated, reduced and acylated according to manufacturer's recommendations. For the second dimension, $8 \%$ to $18 \%$ Excell gels (Amersham Biosciences) were used. IEF/ SDS PAGE was performed with Multiphor II device (Amersham Biosciences). The anodal SDS buffer strip contained $0.45 \mathrm{~mol} \mathrm{~L}^{-1}$ Tris-acetate, $\mathrm{pH}$ 6.6, and $4 \mathrm{~g} \mathrm{~L}^{-1} \mathrm{SDS}, 0.05 \mathrm{~g} \mathrm{~L}^{-1}$ Orange $\mathrm{G}$, while the cathodal strip contained $0.08 \mathrm{~mol} \mathrm{~L}^{-1}$ Tris, 0.80 mol L-1 Tricine, and $6 \mathrm{~g} \mathrm{~L}^{-1}$ SDS, $\mathrm{pH}$ 7.1. Gels were stained with the Coomassie dye.

\section{Staining in gels}

Gels were stained for GBB-esterase and for cholinesterase activity. Unstained SDS-PAGE gel sections were washed in $100 \mathrm{mmol} \mathrm{L}^{-1}$ sodium phosphate buffer( $\mathrm{pH} 6.8$ ) containing $25 \%$ isopropanol for $15 \mathrm{~min}$ and then in the same buffer without isopropanol for additional $15 \mathrm{~min}$. Gel sections were then incubated in the same buffer containing GBB-O-NF (0.01\%) and 4-benzoylamino-2,5dimethoxybenzenediazonium chloride hemi (zinc chloride) salt, usually termed Fast Blue RR salt $(0.01 \%)$. Staining is based on the formation of an insoluble complex between 1-naphthol hydrolysed from GBB-O-NF and Fast Blue RR salt (13). Cholinesterase staining was carried out essentially as described by Karnovsky and Roots (14). Briefly, gel sections were rinsed three times with water and then with $65 \mathrm{mmol} \mathrm{L}^{-1}$ sodium acetate, $\mathrm{pH}$ 6.0. They were then incubated overnight in a buffer containing $65 \mathrm{mmol} \mathrm{L}^{-1}$ sodium acetate (pH 6.0), $0.5 \mathrm{mg} \mathrm{mL}^{-1}$ acetylthiocholine, $5 \mathrm{mmol} \mathrm{L}^{-1}$ sodium citrate, 3 mmol L $\mathrm{L}^{-1}$ cupric sulphate, and $0.5 \mathrm{mmol} \mathrm{L}^{-1}$ potassium ferricyanide. The reactions were stopped by washing the gels with water.

\section{Preparation of samples for MALDI-TOF}

The excised gel spots were crushed to $1 \mathrm{~mm}^{2}$ sized slices and dehydrated with $50 \%$ acetonitrile. The gel slices were then dried under vacuum and rehydrated with $30 \mu \mathrm{L}$ of $25 \mathrm{mmol} \mathrm{L}^{-1} \mathrm{NH}_{4} \mathrm{HCO}_{3}(\mathrm{pH}$ 8.3). Proteins in the gel slices were digested overnight with $25 \mathrm{mg} \mathrm{mL}^{-1}$ of modified trypsin (Promega, Madison, WI, USA) at $37^{\circ} \mathrm{C}$. The peptides were then washed twice from the gel with $50 \mu \mathrm{L} 5 \%$ TFA in $50 \%$ acetonitrile. The wash-outs were collected and dried under vacuum. For MALDI-TOF, peptides were diluted in $3 \mu \mathrm{L}$ of $50 \%$ acetonitrile solution which contained $0.01 \%$ trifluoracetic acid (TFA). $0.8 \mu \mathrm{L}$ of each sample with matrix (alpha-cyano-4hydroxycinnamic acid) were loaded on a MALDI plate. Analysis was performed on a MALDI-TOF mass spectrometer (Perspective Biosystems, Framingham, MA, USA). Data from the EMBL database PeptIdent were used for peptide identification.

\section{Determination of protein concentrations}

During purification, protein content in chromatography fractions was determined by measuring absorbance at $280 \mathrm{~nm}$. In the pooled samples, protein concentrations were determined with Bradford's method (15), using BSA as a standard. 


\section{RESULTS}

\section{Applicability of the assay}

GBB-esterase activity in rat blood serum used to be determined with phenylated gamma-butyrobetaine as an artificial substrate. This assay was rather complicated and time-consuming, as the reaction products were detected by HPLC (9). We have developed a new assay which enables spectrophotometric or colorimetric determination of the reaction products. For this purpose, we synthesized gamma-butyrobetaine 1naphthyl ester. Hydrolysis of this ester should lead to a release of 1-naphthol, which increases optical absorbance at $322 \mathrm{~nm}$ (Figure 1). As 1-naphthol forms an insoluble complex with Fast Blue RR dye it has found its application in determining GBB-esterase activity in gels. Hydrolysis of 1-naphtylacetate is successfully used to determine acetylcholinesterase activity in gels. At the initial stage of the study, it was important to test the applicability and specificity of gamma-butyrobetaine 1-naphthyl ester. This was performed using inhibitor analysis. Native or partially fractionated rat blood serum can hydrolyse gamma-butyrobetaine naphtyl ester, and the reaction can be observed by monitoring the absorbance at $322 \mathrm{~nm}$. Acetylcholine $\left(0.1 \mathrm{mmol} \mathrm{L}^{-1}\right)$ had no effect on the reaction rate and did not compete with the enzyme substrate. In contrast, phenylated gamma butyrobetaine ethyl ester in the same concentration significantly decreased the reaction rate, as did gamma butyrobetaine ethyl and methyl esters. This indicated that the enzyme which hydrolysed gammabutyrobetaine 1-naphthyl esters was inhibited by GBB-esters, and therefore confirmed GBB-esterase activity. In the remainder of this paper, the GBB$\mathrm{O}-\mathrm{NF}$ esterase activity will be called GBB-esterase activity.

\section{Purification of GBB-esterase: selection of optimal protocol}

Several purification protocols were applied during the early stages of the study. Salting out with $\left(\mathrm{NH}_{4}\right)_{2} \mathrm{SO}_{4}$ turned out to be ineffective, as enzymatic activity was lost in high salt concentrations. Enzyme activity was also lost during fractionation on DEAE Sepharose at $\mathrm{pH}$ 7.4. Fractionation on Biogel P150 was also ineffective (not shown). After fractionation on DEAE Sepharose at $\mathrm{pH} 4.2$, GBB-esterase activity was found in a fraction eluted by $0.05 \mathrm{~mol} \mathrm{~L}^{-1} \mathrm{NaCl}$. If the active fraction obtained in the previous procedure was applied on the DEAE Sepharose at $\mathrm{pH} 6.5$ and eluted with (0 to 0.5$) \mathrm{mol} \mathrm{L}^{-1} \mathrm{NaCl}$ gradient, activity was detected in the fraction eluted at $0.315 \mathrm{~mol} \mathrm{~L}^{-1}$. Protein composition of the fraction was still complex (not shown). When the activity-containing fraction obtained after fractionation on DEAE Sepharose at pH 4.2 was dialysed, concentrated, and/or applied to a heparin Sepharose column at $\mathrm{pH} 7$, proteins were eluted by ( 0 to 0.5$) \mathrm{mol} \mathrm{L}^{-1} \mathrm{NaCl}$ gradient. Enzyme activity was detected in a fraction eluted with $0.125 \mathrm{~mol} \mathrm{~L}^{-1} \mathrm{NaCl}$. In this case only four protein bands were detected by Coomassie staining (not shown). Fractionation on DEAE Sepharose at $\mathrm{pH} 4.2$ with procainamide - Sepharose 4B chromatography turned out to be the most effective protocol (16).

\section{Inhibitory analysis of GBB-esterase activity of the fraction obtained on DEAE Sepharose chromatography at $\mathrm{pH} 4.2$}

Inhibitory analysis of the enzyme hydrolysing gamma-butyrobetaine 1-naphthyl esters in the partially purified fraction of rat blood serum on DEAE Sepharose column at $\mathrm{pH} 4.2$ showed that GBBesterase was not inhibited by acetylthiocholine iodide, which is known as a substrate of cholinesterases, or<smiles></smiles> 
by BW 284c51 (1,5 bis \{4-allyldimethyl ammonium phenyl pentane-3-one dibromide), which is a specific inhibitor of acetylcholinesterase. However iso-OMPA, a specific vertebrate butyrylcholinesterase inhibitor, partly inhibited this activity. Inhibition was obtained with butyrylcholine, GBB-methylester, GBBethylester, and phenylated GBB ethyl ester. All these data preclude any role of acetylcholinesterase in the hydrolysis of GBB-esters, but point to another specific enzyme. Involvement of butyrylcholinesterase cannot be excluded (Table 1).

Purification of the protein fraction enriched with GBB-esterase activity for $2 D$ electrophoresis

Serum was dialysed against acetate buffer at $\mathrm{pH}$ 4.2. The dialysate was fractionated by ionic exchange chromatography on DEAE Sepharose at $\mathrm{pH}$ 4.2. Fractions manifesting GBB-esterase activity (Figure 2 ) were pooled and subjected to chromatography on a procainamide column. Procainamide is a ligand

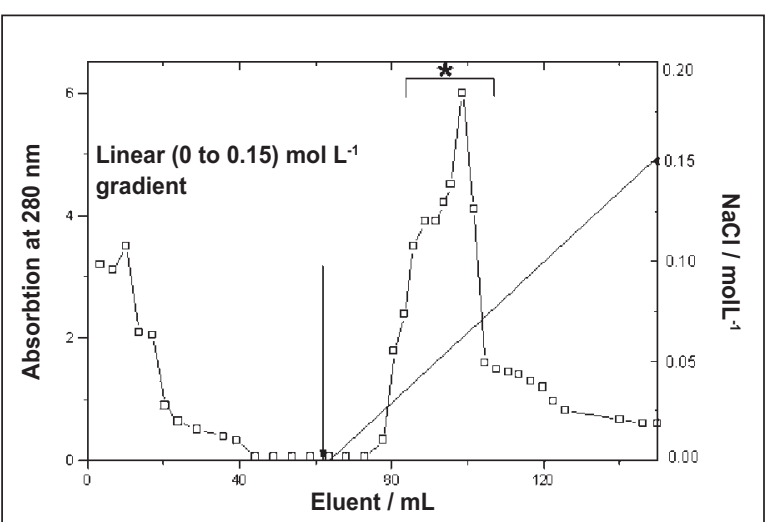

Figure 2 Fractionation on DEAE Sepharose column at $p H$ 4.2. Active fraction of the enzyme was eluted with $0.05 \mathrm{~mol} \mathrm{~L} \mathrm{~L}^{-1} \mathrm{NaCl}$ in $25 \mathrm{~mL}$ of $0.02 \mathrm{~mol} \mathrm{~L}^{-1} \mathrm{Na}$ acetate buffer at $p H$ 4.2. The bracket indicates pooled active fractions used for further purification.

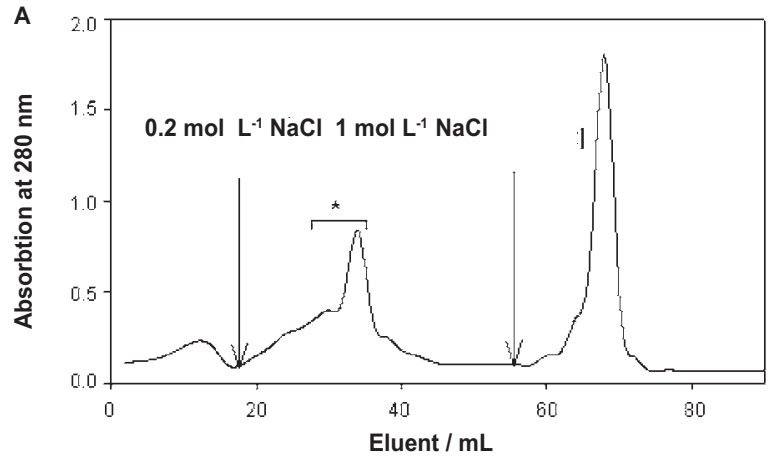

B

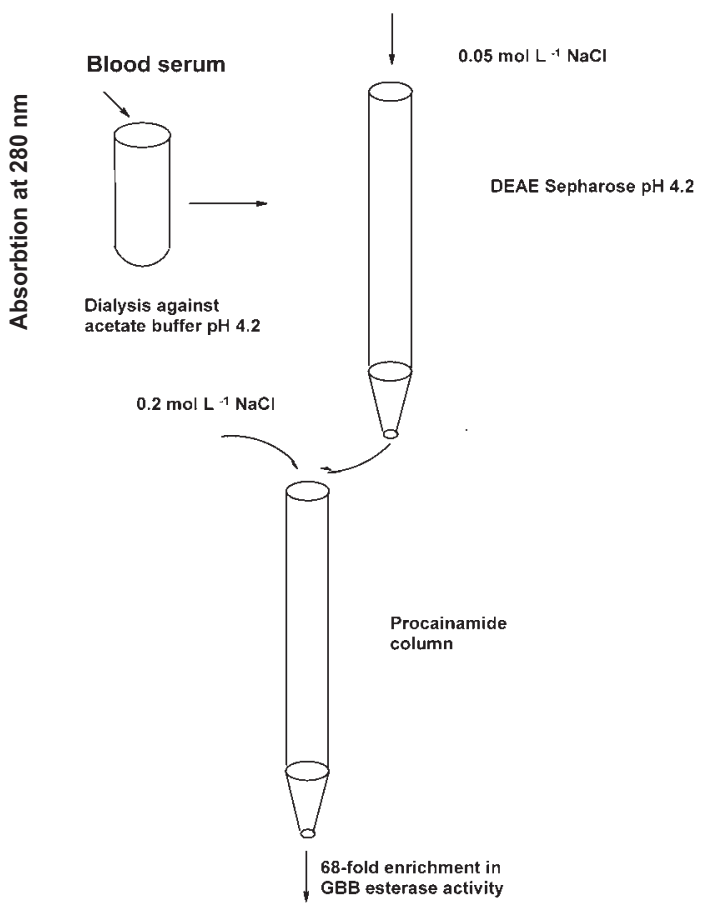

Figure 3 A - Fractionation on the procainamide Sepharose column at $\mathrm{pH}$ 7.0. The GBB-O-NF esterase active fractions were eluted with $0.2 \mathrm{~mol} \mathrm{~L}^{-1} \mathrm{NaCl}$ in buffer. Bracketed fractions were pooled. The remaining proteins were eluted with $1 \mathrm{~mol} \mathrm{~L}^{-1} \mathrm{NaCl}$. $B$ - Purification steps of protein fraction enriched with GBB-esterase activity.

Table 1 Effect of potential inhibitors on GBB-esterase activity in rat blood serum fraction obtained on DEAE Sepharose and on purified carboxylesterase from horse blood serum. All substances were applied in a $0.1 \mathrm{mmol} \mathrm{L}^{-1}$ concentration; experiments were repeated in triplicate.

\begin{tabular}{lcc}
\hline \multirow{2}{*}{ Compound } & \multicolumn{2}{c}{ Effect on GBB-esterase activity (remaining activity) } \\
\cline { 2 - 3 } & $\begin{array}{c}\text { Active fraction of blood } \\
\text { serum / \% activity }\end{array}$ & $\begin{array}{c}\text { Carboxylesterase / } \\
\text { \% activity }\end{array}$ \\
\hline Acetylthiocholine & No effect & 10 \\
\hline Butyrylcholine & 20 & 10 \\
\hline Gamma butyrobetaine methyl ester & 58 & 4 \\
\hline Gamma butyrobetaine ethyl ester & 47 & 20 \\
\hline Phenyl gamma butyrobetaine ethyl ester & 21 & 10 \\
\hline Izo-OMPA & 50 & 10 \\
\hline BW 284c51 & No effect & 20 \\
\hline
\end{tabular}


Table 2 Steps in the partial purification of GBB-esterase activity. The unit of GBB-O-NF esterase is defined as the amount of enzyme which catalyses the formation of $1 \mu \mathrm{mol}$ of 1 -naphthol $\left(2.2 \mathrm{~L} \mathrm{mmol}^{-1} \mathrm{~cm}^{-1} \mathrm{~min}^{-1}\right.$ under optimal conditions (100 $\mathrm{mmol} \mathrm{L}^{-1}$ sodium phosphate buffer, $\mathrm{pH}$ 7.4; $0.1 \mathrm{mmol} \mathrm{L}^{-1} \mathrm{GBB}-\mathrm{O}-\mathrm{NF}$ ).

\begin{tabular}{lccccc}
\hline Step & $\begin{array}{c}\text { Total } \\
\text { protein / }\end{array}$ & Total activity / U & $\begin{array}{c}\text { Specific activity / } \\
\mathbf{U} \text { mg }^{-1}\end{array}$ & $\begin{array}{c}\text { Yield / \% } \\
\text { Increase in } \\
\text { activity }\end{array}$ \\
\hline $\begin{array}{l}\text { Dialysed blood serum, } \\
\text { pH 4.2 }\end{array}$ & 700 & 1190 & 1.7 & 100 & 1 - fold \\
\hline $\begin{array}{l}\text { DEAE Sepharose } \\
\text { chromatography }\end{array}$ & 29.6 & 855 & 28.9 & 72 & 17 - fold \\
\hline $\begin{array}{l}\text { Procainamide sepharose } \\
\text { chromatography }\end{array}$ & 3.96 & 456 & 115.2 & 38 & 68 - fold \\
\hline
\end{tabular}
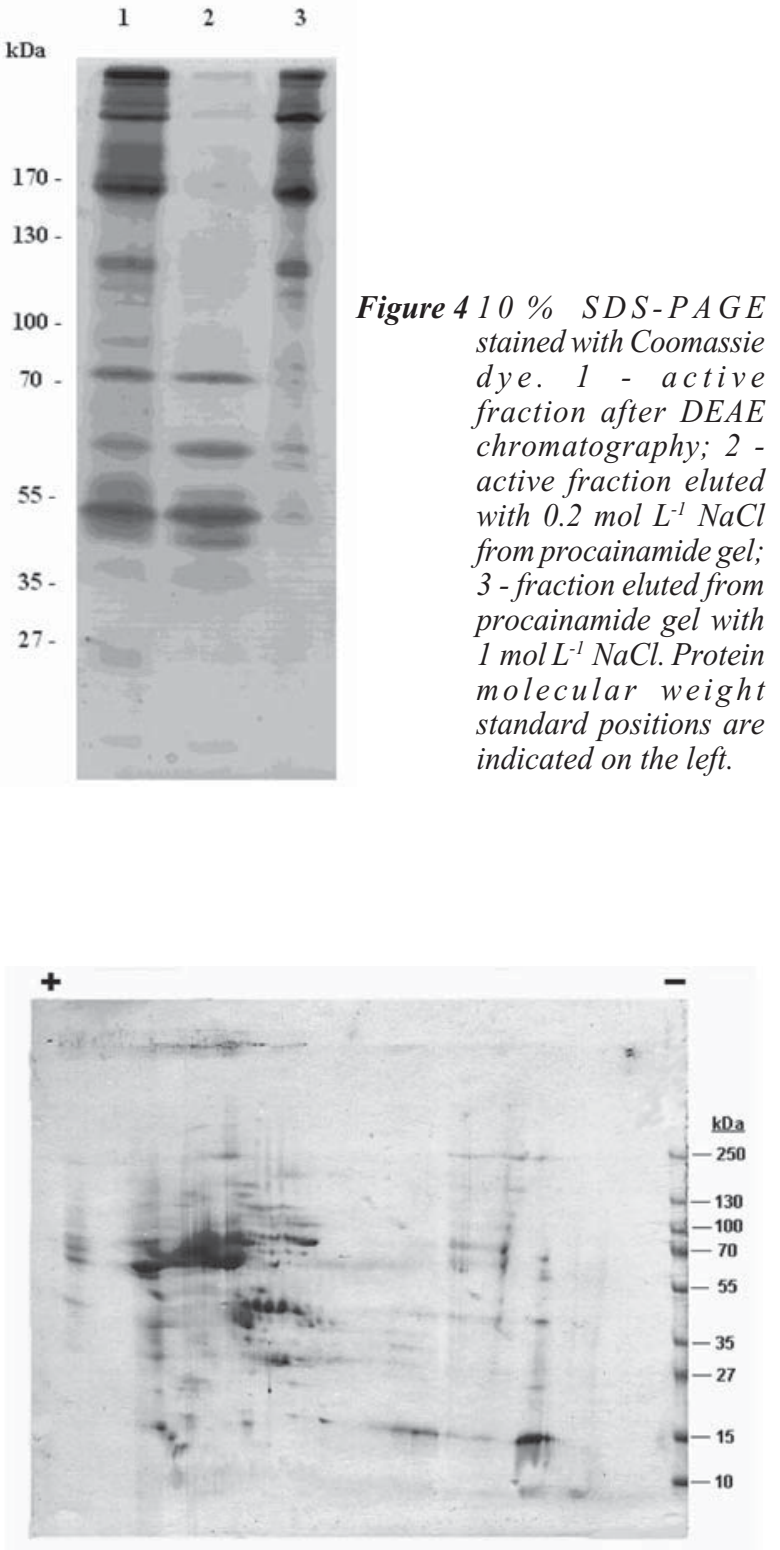

Figure 62 D electrophoresis of $150 \mu \mathrm{g}$ of active fraction after DEAE Sepharose fractionation. First dimension - Immobiline Dry Strips; pH 3 to 10; Coomassie stained gel.

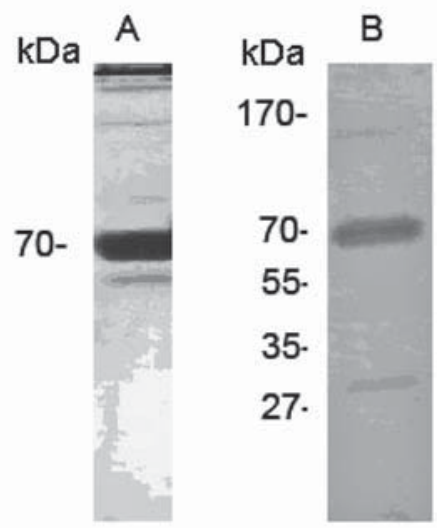

Figure 5 A $-7.5 \%$ native PAGE of the fraction eluted with $0.2 \mathrm{~mol} \mathrm{~L} \mathrm{~L}^{-1} \mathrm{NaCl}$ from procainamide gel stained for GBB-O-NF esterase activity; $B-10 \%$ SDS PAGE of the fraction eluted with $0.2 \mathrm{~mol} L^{-1} \mathrm{NaCl}$ from procainamide gel stained for GBB-O-NF esterase activity.

specific for the choline binding site. Procainamide affinity chromatography was found to be efficient for purifying most cholinesterases (16), as procainamide is structurally related to choline and also to gammabutyrobetaine.

Proteins with GBB-esterase activity were eluted with $0.2 \mathrm{~mol} \mathrm{~L}^{-1} \mathrm{NaCl}$. Proteins bound more tightly to procainamide were eluted with $1 \mathrm{~mol} \mathrm{~L}^{-1} \mathrm{NaCl}$ (Figure 3). Table 2 shows GBB esterase purification data, while Figure 3B shows the steps that led to it.

We achieved a 68-fold increase in specific activity. The active fraction in SDS-gels was represented by several polypeptides (Figure 4). Staining native gels of the active fraction for GBB-esterase activity revealed several bands (Figure 5A). One of them contained about $95 \%$ of the total GBB-esterase activity. Four distinct bands of $160 \mathrm{kDa}, 70 \mathrm{kDa}, 56 \mathrm{kDa}$, and 


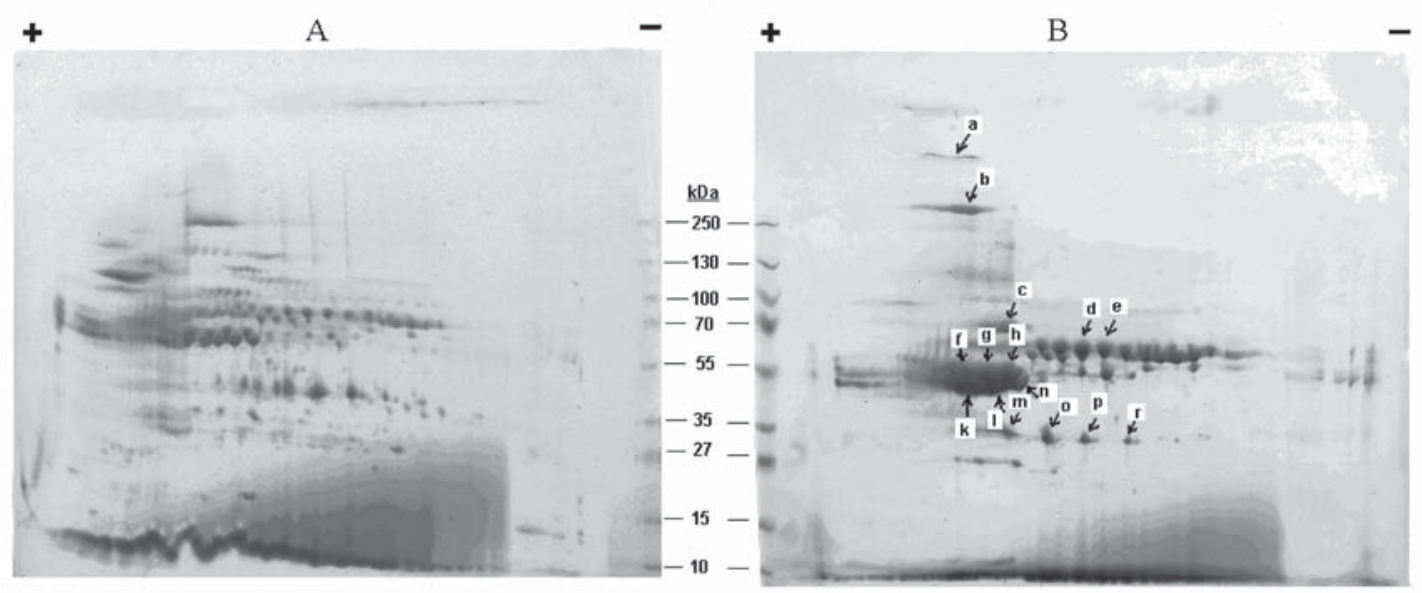

Figure $72 D$ electrophoresis patterns: A - $180 \mu \mathrm{g}$ of active fraction after DEAE Sepharose fractionation; $B$ - $150 \mu \mathrm{g}$ of active fraction after procainamide gel fractionation. First dimension - Immobiline Dry Strips; $p H 4$ to 7; a-r denotes spots which were subjected to MALDI-TOF

Table 3 Characterised proteins of the partially purified GBB-esterase fraction after separation with 2D electrophoresis.

\begin{tabular}{|c|c|c|c|c|}
\hline Spot & Protein name & $\begin{array}{c}\text { MW / } \\
\text { kDa }\end{array}$ & pI & Protein function \\
\hline $\mathrm{a}$ & $\begin{array}{l}\text { Ubiquitin carboxyl- } \\
\text { terminal hydrolase }\end{array}$ & 128 & 5.3 & Cleaves ubiquitin fusion protein substrates \\
\hline $\mathrm{b}$ & Liver carboxylesterase & 58 & 5.5 & $\begin{array}{l}\text { Involved in the detoxification of xenobiotics and in the } \\
\text { activation of ester and amide prodrugs. Catalyses the } \\
\text { following reaction: A carboxylic ester }+\mathrm{H}_{2} \mathrm{O}=\text { an alcohol } \\
+ \text { a carboxylate. Belongs to the type- } \mathrm{B} \text { carboxylesterase/ } \\
\text { lipase family }\end{array}$ \\
\hline $\mathrm{c}$ & Calretinin & 31 & 4.9 & Calcium-binding protein abundant in auditory neurons \\
\hline $\mathrm{d}$ & $\begin{array}{l}\text { Ras-related protein } \\
\text { Rab-3A }\end{array}$ & 25 & 4.9 & $\begin{array}{l}\text { Involved in exocytosis by regulating a late step in synaptic } \\
\text { vesicle fusion. Could play a role in neurotransmitter release } \\
\text { by regulating membrane flow in the nerve terminal I }\end{array}$ \\
\hline e & Cytosol aminopeptidase & 56 & 6.8 & $\begin{array}{l}\text { Presumably involved in the processing and regular turnover of } \\
\text { intracellular proteins. Catalyzes the removal of unsubstituted } \\
\text { N-terminal amino acids from various peptides }\end{array}$ \\
\hline$f$ & Acetylcholinesterase & 65 & 5.7 & Rapidly hydrolyzes choline released into the synapse \\
\hline $\mathrm{g}$ & Alpha-2-HS-glycoprotein & 36 & 6.0 & $\begin{array}{l}\text { Presumably inhibits both insulin-receptor tyrosine } \\
\text { kinase activity and insulin-stimulated receptor } \\
\text { autophosphorylation }\end{array}$ \\
\hline $\mathrm{h}$ & $\begin{array}{l}\text { Stress-induced- } \\
\text { phosphoprotein } 1\end{array}$ & 63.6 & 4 & $\begin{array}{l}\text { Mediates the association of the molecular chaperones } \\
\text { HSC } 70 \text { and HSP } 90\end{array}$ \\
\hline $\mathrm{k}$ & Alpha-1-antiproteinase & 44 & 5.6 & Proteinase inhibitor \\
\hline 1 & Alpha-1-antiproteinase & 44 & 5.6 & Proteinase inhibitor \\
\hline $\mathrm{m}$ & Cytosol aminopeptidase & 56 & 6.8 & \\
\hline $\mathrm{n}$ & $\begin{array}{l}\text { Haptoglobin beta chain } \\
\text { peptidase } \mathrm{S} 1\end{array}$ & 27 & 6.3 & Transport of released hemoglobin \\
\hline o & Haptoglobin beta chain & 27 & 6.3 & \\
\hline $\mathrm{p}$ & Haptoglobin beta chain & 27 & 6.3 & \\
\hline $\mathrm{r}$ & Haptoglobin & 37 & 6.0 & \\
\hline
\end{tabular}


$35 \mathrm{kDa}$ were seen on SDS-PAGE gels stained for GBB-esterase activity. The $70 \mathrm{kDa}$ band contained about $95 \%$ of the total activity (Figure $5 \mathrm{~B}$ ). Some of the above bands also manifested cholinesterase activity; however, the distribution of both activities was not identical (not shown).

\section{$2 D$ electrophoresis and characterisation of proteins}

The results of two-dimensional electrophoresis of the fraction obtained with DEAE Sepharose chromatography are shown in Figure 6. Figure 7 shows two-dimensional electrophoretic separation of active fractions after DEAE Sepharose chromatography and chromatography on a procainamide column in a narrow $\mathrm{pH}$ gradient ( $\mathrm{pH} 4$ to 7 ). The marked spots were excised and taken for MALDI-TOFF analysis. Table 3 summarises information about the characterised proteins. Carboxylase appeared to be the most suitable for hydrolysing GBB-esters in blood serum. To test this possibility, we measured the activity of commercially available horse liver carboxylase using the standard assay. Carboxylase manifested GBB-esterase activity, but unlike the GBB-esterase-containing fraction of the blood serum, it was sensitive to all inhibitors tested (Table 1). Its high sensitivity to gamma butyrobetaine methyl ester suggests that the enzyme does indeed possess GBB-esterase activity.

\section{DISCUSSION}

This study has shown that enzymatic hydrolysis of GBB naphthyl ester to 1-naphthol in rat blood serum is due to GBB-esterase activity. Our previous results (9) indicated that acetylcholine esterase and butyrylcholinesterase were incapable of performing this reaction. We therefore looked further by combining DEAE Sepharose at $\mathrm{pH} 4.2$ and affinity chromatography with procainamide to achieve a 68 fold enrichment in GBB-esterase activity. Further characterization indicated that carboxylase was an important component of this fraction. We observed high GBB-esterase activity in a band of about $70 \mathrm{kDa}$ in one-dimensional native and SDS electrophoresis (Figure 5). The molecular weight of carboxylase released in serum is $71 \mathrm{kDa}(13)$. In $2 \mathrm{D}$ electrophoresis the protein was detected in a high-molecular weight complex; the reason for this might be the level of glycosylation. Alternatively, we may have detected some other carboxylase isoenzyme. Carboxylases are homologous to a large extent (17). This conclusion was confirmed by the fact that partially purified enzyme preparations from rat blood serum and purified horse liver carboxylesterase were sensitive to different inhibitors. We believe that there may be one or more other enzymes which are also able to hydrolyse GBBesters. These could form the high-molecular complex observed on 2D gel together with carboxylesterase.

The hydrolysis of GBB-esters by carboxylesterase indicates the physiological significance of the substance. Along with blood acetylcholinesterase, butyrylcholinesterase, and paraoxonase, this enzyme is involved in detoxifying numerous hazardous substances, including organophosphates $(18,19)$. It interacts with a broad range of substrates and performs arylesterase activity (20). It is likely to protect against excessive amounts of GBB-esters synthesised in other organs for functional purposes. As GBB-esters trigger a strong cholinergic reaction (21-23), in excess they could be dangerous. An investigation of GBBesterases in other organs, especially in the brain, might shed more light on the functional significance of GBB-esters.

\section{Acknowledgements}

This work was supported by the Taiwanese-LatvianLithuanian project "Purification and characterisation of the gamma-butyrobetaine esterase".

\section{REFERENCES}

1. Hosein EA, Proulx P. Acetylcholine-like activity in subcellular particles isolated from rat brain. Arch Biochem Biophys 1964;106:267-74.

2. Hosein EA, Booth SJ, Gasoi I, Kato G. Neuromuscular blocking activity and other pharmacologic properties of various carnitine derivatives. J Pharmacol Exp Ther 1967; 156:565-72.

3. Hosein EA, Kato A, Vine E, Hill AM. The identification of acetyl-L-carnitylcholine in rat brain extracts and the comparison of its cholinomimetic properties with acetylcholine. Can J Physiol Pharmacol 1970;48:709-22.

4. Hosein EA, Pang D, Tesfaye Y. Some biochemical actions of carnitylcholine, a neuromuscular blocking agent. Biochem Pharmacol 1971;20:3385-95.

5. Kalvinsh I, Gutcaits A, Bagdoniene L, Labeikyte D, Trapencieris P, Sjakste N. Hypothetical gamma-butyrobetaine esterase-dependent signal transduction system: possible link to mildronate action. Med Hypotheses Res 2006;3:803-12.

6. Sjakste N, Kalvinsh I. Mildronate: an antiischemic drug with multiple indications. Pharmacologyonline 2006;1:118. 
7. Sjakste N, Gutcaits A, Kalvinsh I. Mildronate: An antiischemic drug for neurological indications. CNS Drug Reviews 2005;11:151-68.

8. Thomizek WD, Strack E, Lorenz J. Über den Einfluß einiger Derivate aliphatischen Trimethylbetaine auf die Acetylcholine-esterase und über die Hydrolyse von Betainestern [About influence of some aliphatic derivatives of trimethylbetaine on acetylcholine esterase and about hydrolysis of betaine esters, in German]. Acta Biol Med Germ 1963;11:353-55.

9. Orbidāne O, Meirena D, Pugovičs O, Dzintare M, Sjakste J, Kalviņš I, Sjakste N. Gamma-butyrobetaine esterase activity in rat blood serum. Proc Latv Acad Sci B 2004;58:98-102.

10. Morgan EW, Yan B, Greenway D, Petersen DR, Parkinson A. Purification and characterization of two rat liver microsomal carboxylesterases (hydrolases A and B). Arch Biochem Biophys 1994;315:495-512.

11. Cuatrecasas P. Protein purification by affinity chromatography: derivatizations of agarose and polyacrylamide beads. J Biol Chem 1970;245:3059-65.

12. Laemmli UK. Cleavage of structural proteins during the assembly of the head of bacteriophage T4. Nature 1970;227:680-5.

13. Yan B, Yang D, Bullock P, Parkinson A. Rat serum carboxylesterase: Cloning, expression, regulation, and evidence of secretion from liver. J Biol Chem 1995;270:1912834.

14. Seidman S, Sternfeld M, Ben Aziz-Aloya R, Timberg R, Kaufer-Nachum D, Soreq H. Synaptic and epidermal accumulations of human acetylcholinesterase are encoded by alternative 3-terminal exons. Mol Cell Biol 1995;15:29933002.

15. Bradford MM. A rapid and sensitive method for the quantitation of microgram quantities of protein utilizing the principle of protein-dye binding. Anal Biochem 1976;72:248-54.

16. Lockridge O, Schopfer LM, Winger G, Woods JH. Large scale purification of butyrylcholinesterase from human plasma suitable for injection into monkeys; a potential new therapeutic for protection against cocaine and nerve agent toxicity. J Med CBR Defense 2005;3:1-23.

17. Satoh T, Hosokawa M. The mammalian carboxylesterases: from molecules to functions. Annu Rev Pharmacol Toxicol 1998;38:257-88.

18. Wheelock CE, Phillips BM, Anderson BS, Miller JL, Miller MJ, Hammock BD. Applications of carboxylesterase activity in environmental monitoring and toxicity identification evaluations (TIEs). Rev Environ Contam Toxicol 2008;195:117-78.

19. Nigg HN, Knaak JB. Blood cholinesterases as human biomarkers of organophosphorus pesticide exposure. Rev Environ Contam Toxicol 2000;163:29-111.

20. Connelly PW, Maguire GF, Draganov DI. Separation and quantitative recovery of mouse serum arylesterase and carboxylesterase activity. J Lipid Res 2004;45:561-6.

21. Meerson FZ, Abdikaliev NA, Kalvin'sh II, Vovk VI. Bioélektricheskiĭ mekhanizm antiaritmicheskogo deı̌stviia sinteticheskogo analoga atsetilkholina EDIGI [Bioelectrical mechanism of the anti-arrhythmia effect of a synthetic acetylcholine analog EDIHYP, in Russian]. Kardiologiia 1991;31:52-5

22. Meerson FZ, Kalvin'sh II, Abdukaliev NA. Ustranenie narusheniǐ élektricheskoĭ stabil'nosti serdtsa i aritmii s pomoshch'iu sinteticheskogo analoga atsetilkholina [Correction of disorders of electric stability of the heart and arrhythmia by using a synthetic analog of acetylcholine, in Russian]. Biull Eksp Biol Med 1991;111:13-6.

23. Abdikaliev NA, Kalvin'sh II, MeersonFZ. Антиаритмическое действие синтетического аналога ацетилхолина EDIHYP на нарушения сердечного ритма, вызванные хлоридом кальция и строфантином. [The antiarrhythmic action of the synthetic acetylcholine analog EDIHYP in calcium chlorideand strophanthin-induced heart rhythm disorders, in Russian]. Farmakol Toksikol 1991;54:25-8. 
Sažetak

\section{KARBOKSILESTERAZA DJELOMICE HIDROLIZIRA ESTERE GAMA-BUTIROBETAINA U SERUMU ŠTAKORA}

Premda su poznati već neko vrijeme, esteri gama-butirobetaina (GBB) i srodni spojevi nisu dobili mnogo pozornosti u znanstvenoistraživačkoj zajednici, a njihova fiziološka funkcija i dalje je nerazjašnjena. U ranijem smo istraživanju HPLC-metodom otkrili enzimsku aktivnost GBB-esteraze u serumu štakora rabeći umjetni supstrat ovoga enzima, tj. fenilirani gama-butirobetain. Cilj ovoga istraživanja bio je razviti pretragu koja će omogućiti spektrofotometrijsko ili kolorimetrijsko određivanje reakcijskih produkata nastalih aktivnošću GBB-esteraze te utvrditi koji pojedinačni proteini u serumu štakora posjeduju aktivnost GBB-esteraze. U tu je svrhu sintetiziran gama-butirobetain 1-naftil ester. Njegovom hidrolizom otpušta se 1-naftol koji povećava optičku apsorbanciju na $322 \mathrm{~nm}$. Pokazali smo da u hidrolizi GBB 1-naftil estera u 1-naftol u serumu štakora sudjeluje GBB-esteraza. Pokušali smo pročistiti enzim iz štakorskoga seruma. Kombinacijom DEAE sefaroze pri pH 4,2 i afinitetne kromatografije s prokainamidom dobili smo 68-erostruko povećanje aktivnosti ovoga enzima. Razdvajanjem bjelančevina iz frakcije s pomoću 2D elektroforeze te naknadnom spektrometrijom masa utvrđeno je da u serumu štakora esteraznu aktivnost prema gama-butirobetainu kao supstratu djelomice provodi karboksilesteraza.

KLJUČNE RIJEČI: 2D elektroforeza, HPLC, kolorimetrija, 1-naftol, spektrofotometrija

CORRESPONDING AUTHOR:

Nikolajs Sjakste

Latvian Institute of Organic Synthesis,

Aizkraukles Street 21, Riga

LV1006, Latvia

E-mail:Nikolajs.Sjakste@lu.lv 